\title{
Influence of bunch bagging on the development of banana Prata (AAB) and prevention of chilling injury in the field
}

\author{
Juliana Domingues Lima ${ }^{1 *}$, Danilo Eduardo Rozane ${ }^{1}$, Eduardo Nardini Gomes ${ }^{1}$, Silvia Helena Modenese \\ Gorla da Silva ${ }^{1}$, Wilson da Silva Moraes ${ }^{2}$, Ricardo Alfredo Kluge ${ }^{3}$ \\ ${ }^{1}$ São Paulo State University, UNESP, Registro, São Paulo, Brazil \\ ${ }^{2}$ Agency Paulista de Tecnologia dos Agronegócios, APTA, Registro, Brazil \\ ${ }^{3}$ University of São Paulo, USP, Department of Biological Sciences, Piracicaba, Brazil
}

*Corresponding author: judlima@registro.unesp.br

\begin{abstract}
Banana is extremely sensitive to chilling injury $(\mathrm{Cl})$. It shows symptoms of peel browning at approximately $12^{\circ} \mathrm{C}$ and severe symptoms at $6^{\circ} \mathrm{C}$. The purpose of this study was to investigate the influence of different bagging materials on development of banana bunch (Musa spp. AAB cv. Prata) and preventing $\mathrm{Cl}$ in field. The study was carried in Jacupiranga, São Paulo, Brazil, in a completely randomized design in $2 \times 9$ factorial, in which treatments were two years of formation of bunch and nine bagging materials, with eight replicates. Bagging was performed in the autumn and winter to ensure the occurrence of $\mathrm{Cl}$ in the field, and the evaluations after harvesting and fruit maturation. The bagging materials consisted of blue transparent polyethylene, white nonwoven fabric, white opaque polyethylene, bubble wrap, white laminated non-woven fabric, double paper, blue transparent polyethylene plus kraft paper, blue transparent polyethylene plus white non-woven fabric and non-bagged. In 2013, the bunches of were exposed to $182.02 \mathrm{~h}$ of temperatures lower than $12^{\circ} \mathrm{C}$ and $5.25 \mathrm{~h}$ of temperatures lower than $5^{\circ} \mathrm{C}$, while in 2014 , only $70.76 \mathrm{~h}$ of temperatures lower than $12^{\circ} \mathrm{C}$ was provided. Bunches formed in 2013 had longer exposure periods between flowering and harvest due to the low temperatures, but exhibited higher mass than those formed in 2014 . The $\mathrm{Cl}$ index was only 1.38 in 2013 and 1.00 in $2014(p<0.05)$. On the colder days of 2013 and 2014, bagging raised peel temperature 1.91 and $3.17^{\circ} \mathrm{C}$, respectively. The bagging material influenced yield, the accumulation of nutrients in fruits and the hue angle of peel. Double paper promoted fruits with more yellow peel.
\end{abstract}

Keywords: Abiotic stress, Musa spp., Bunch cover, Cold, Browning.

Abbreviations: $\mathrm{Cl}$ _chilling injury (Cl); NB_Non-bagged; BTP_blue transparent polyethylene; WNF_white non-woven fabric; WOP_white opaque polyethylene; BW_bubble wrap; WLNF_white laminated non-woven fabric; DP_double paper; BTP+KP_blue

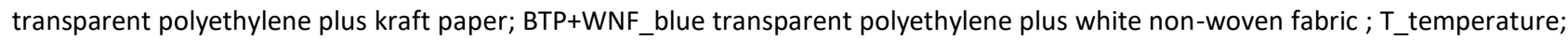
Tmin_minimum temperature; Tmax_maximum temperature; PFH_period between flowering and harvest; BM_bunch mass; SM_stalk mass; HN_hand number; $\overline{C l}$ index_ chilling injury index; $a^{*}$ _coordinated $a^{*} ; b^{*}$ _coordinated $b^{*}$; $L^{*} \_b r i g h t n e s s ;$ C*_chromaticity; $\mathrm{h}_{\text {_ }}^{\circ}$ hue angle; SL_shelf life; PM_mass loss; F_firmness; TSS_total soluble solids; TA_titratable acidity; SS_soluble sugars; S_starch; DMpeel_dry mater peel; Mpulp_dry matter pulp; N_nitrogen; P_phosphorus; K_potassium; Ca_calcium; Mg_magnesium; S_sulfur; B_boron; Cu_copper; Fe_iron; Mn_manganese; Zn_zinc.

\section{Introduction}

Banana (Musa spp.) is considered an important perennial crop in the tropical and subtropical regions (Bidabadi et al., 2011). Temperature, humidity and rainfall need to be high $\left(22-31^{\circ} \mathrm{C}, 2,000\right.$ to $2500 \mathrm{~mm}$ year ${ }^{-1}$ ) (Robinson and Saúco, 2012) and evenly distributed for optimal growth and high yield of fruits (Zhang et al., 2012).

In subtropical or marginal regions, banana production is often threatened by low temperature, causing reduced growth, slower development of plants (Zhang et al., 2012). Furthermore, the stress caused by such low temperature can lead to extensive damage to the plants (Zhang et al., 2012) and its fruits, which strongly affect the quality and marketability (Hashim et al., 2012).
Banana is extremely sensitive to chilling injury $(\mathrm{Cl})$, i.e. they show mild symptoms at relatively high temperatures $\left(12^{\circ} \mathrm{C}\right)$ compared to other fruits (Nguyen et al., 2003), because it is of tropical origin (Robinson and Saúco, 2012) and severe symptoms at $6^{\circ} \mathrm{C}$ (Nguyen et al., 2003). The most common symptoms of $\mathrm{Cl}$ in banana are dark peel areas (browning) and scald-like discoloration (Nguyen et al., 2003; Hashim et al., 2012).

The covering of banana bunch is a physical protection method that improves most of the external quality characteristics, creates a microclimate that can reduce the flower-to-harvest interval days and increase bunch mass depend on the material of cover and the environmental 
conditions (Santosh et al., 2017). This is partly due to increased temperature that is conducive for enhanced metabolic reactions and growth (Muchui, 2012). It also prevents $\mathrm{Cl}$ during the cool winter months (Harvey et al., 2006; Kutinyu et al., 2014; Pathak et al., 2017).

The bagging materials being used to protect banana bunch differ in their composition, thickness, color, degree of perforation and number of layers (Mustafá and Kumar, 2012; Santosh et al., 2017; Pathak et al., 2017). They can improve the efficiency of field chilling prevention depending of design (Harvey et al., 2006). Optical and thermal characteristics of covering material vary in function of their chemical and physical properties as well as radiative heat transfer process (Al-Mahdouri et al., 2013).

Under severe winter conditions in Tule, Australia, banana cv. Willians was subjected to cumulative stress temperature during bunch development. It exhibited reduction of $\mathrm{Cl}$ using the non-sealed silver blue + silver bubble cover relative to fruit from blue polyethylene covers (Harvey, 2006), which is the most commonly used bagging material (Robinson and Saúco, 2012). In Mozambique, Africa, the polyethylene in different designs (color and perforation) allowed the elevation of the temperature inside the bags and increased yield of Grand Naine and Williams banana cultivars with significant reduction of $\mathrm{Cl}$ and and other fruit defects (Kutinyu et al., 2014). However, the minimum temperature reached on the surface of the peel was only $12.1^{\circ} \mathrm{C}$. This demonstrates that covering of bunch can be exploited for trapping solar energy heat inside and/or suppressing the outside environment convection. Other materials besides the polyethylene have been used to cover the banana bunch, such as non-woven fabric (polypropylene) and paper (Mustaffa and Kumar, 2012, Pathak et al., 2017a; 2017b, Santosh et al., 2017). However, there are no reports in the literature about its effects on $\mathrm{Cl}$ prevention. The aim of this paper was to investigate the influence of different bagging materials on bunch development of banana (Musa spp. AAB cv. Prata) and occurrence of $\mathrm{Cl}$ in field.

\section{Results and Discussion}

\section{Effect of the year of formation on the characteristics of the bunch and fruits}

There were small differences in average daily temperatures between 2013 and 2014 (Table 1). Nevertheless, the thermal sum accumulated and the number of hours with temperatures capable of inducing $\mathrm{Cl}\left(<12^{\circ} \mathrm{C}\right.$ and $\left.<5^{\circ} \mathrm{C}\right)$ in fruits was higher in 2013 , as well as the precipitation.

The interaction between year of bunch formation and bagging material affected the PFH and BM (Fig 1). Regardless of treatment, PFH was always higher in 2013 than in 2014, probably due to the effect of the low temperature on the fruit filling stage (Table 1). The banana bunches formed in 2013 presented higher PFH, but higher BM than those formed in 2014 (Fig 1), suggesting that although there is a higher occurrence of temperature that could cause $\mathrm{Cl}$ in 2013 (Table 1), the climatic conditions were more suitable for growth. The lower BM and PFH in 2014 were probably due to water availability, which was lower than the $25 \mathrm{~mm}$ week $^{-1}$ considered adequate (Robinson and Saúco, 2012). There were no differences in SM and HN between the two years, indicating that the difference in BM was due to the number or fruit size.

The $\mathrm{Cl}$ symptoms were associated with peel browning around the vascular tissues in bunches formed in 2013, whose average $\mathrm{Cl}$ index was 1.38 , regardless of the bagging material (Table 2). Bunches formed in 2014 did not exhibit $\mathrm{Cl}$. At the same time, a* was more pronounced in bunches formed in 2014, indicating upper red color component, as well as $b^{*}$, indicating yellow. Nevertheless, there were no differences in $L^{*}$ and between the two years of bunch formation, while $C^{*}$ was higher in 2014, indicating higher color purity. The high values of $L^{*}$ exhibited by the fruits formed in the two years also indicates small $\mathrm{Cl}$ index (Table 2), because according to Cho et al. (2016), the CIE L*a*b* system is suitable for evaluating the browning of banana peel. In addition, 100 mature fruits formed in months with no temperature causing $\mathrm{Cl}$ (spring/summer) were evaluated. They generated a desired color pattern $\left(L^{*}, 73.92, C^{*}, 56.67\right.$ and $\left.h^{\circ}, 89.15\right)$. These values show small $\Delta L^{*}$ deviations of $2.38-1.66$; and $\Delta C^{*}$ of -1.95 and -2.66 and $\Delta h^{\circ}$ of -0.89 and 1.59 , respectively, for 2013 and 2014, agreeing with the visual analysis. It should be noted that in 2013, 5.25 hours of temperature lower than $5^{\circ} \mathrm{C}$ was occurred (Table 1). This is a very low value for banana crops, suggesting that cv. 'Prata' has tolerance to cold, in agreement with postharvest studies (Oliveira et al., 2016). The higher tolerance of cv. Prata, compared to cv. Nanicão (AAA) was associated with the cryoprotectant effect of sucrose (Der Agopian et al., 2011). However, no relationship between starch metabolism and fruit peel browning has been established. The F, pH, SST, TA and DMpeel were not influenced by the year of bunch formation (Table 2). The SL, ML and SS were higher in 2014, and on the contrary, S and DMpulp were higher in 2013. Bunches in 2013 were formed under lower temperatures (Table 1), which resulted in longer PFH and accumulated thermal sum and higher physiological maturity of fruits at harvest, plus lower SL (Table 2). In contrast, bunches formed in 2014 exhibited shorter PFH due to water limitation, which consequently resulted in higher SL. The ML was mainly caused by fruit transpiration. It was slightly higher in fruits formed in 2014 compared to 2013, a difference that may be related to the higher SL (Table 2). The SS content was higher in 2014, unlike starch that was lower, compared to 2013 (Table 2); however, differences in TSS content between fruits of two years were not observed, suggesting that these differences are not related to cold tolerance.

The $\mathrm{Mn}$ content in the peel and the $\mathrm{B}, \mathrm{Cu}, \mathrm{Fe}, \mathrm{Mn}$ and $\mathrm{Zn}$ contents in the pulp were not influenced by the year of bunch formation (Table 2). When significant differences between years were observed, nutrient content was always higher in 2013 than in 2014, due to the greater water availability (Table 1 ). For $\mathrm{K}$ and $\mathrm{Fe}$, there was a significant interaction between year of bunch formation and the bagging material. Aquino et al. (2014) found higher levels of $\mathrm{N}, \mathrm{P}, \mathrm{Ca}, \mathrm{Mg}, \mathrm{Cu}, \mathrm{Mn}, \mathrm{Fe}$, and $\mathrm{Zn}$ in the peel of 'Prata' fruits, compared to those obtained in this study. In the pulp, N, $\mathrm{P}$, $\mathrm{K}, \mathrm{Ca}, \mathrm{Mg}, \mathrm{Fe}, \mathrm{Mn}$ and $\mathrm{Zn}$ contents were higher and $\mathrm{Cu}$ contents were close to this study.

\section{Effect of bagging material on bunch and fruit characteristics}

On the colder days of 2013 and 2014, the bunch cover raised 
Table 1. Climatic conditions in the period between flowering (PHF) and harvest of banana cv. 'Prata'.

\begin{tabular}{llllllll}
\hline Year & PHF & $\begin{array}{l}\text { Daily } \\
\mathrm{T} \text { min }{ }^{\circ} \mathrm{C}\end{array}$ & $\begin{array}{l}\text { Daily } \\
\mathrm{Tmax} \\
{ }^{\circ} \mathrm{C}\end{array}$ & $\begin{array}{l}\mathrm{T}<12^{\circ} \mathrm{C} \\
\mathrm{n}^{\circ} \text { of hours* }\end{array}$ & $\begin{array}{l}\mathrm{T}<5^{\circ} \mathrm{C} \\
\mathrm{n}^{\circ} \text { of hours* }\end{array}$ & $\begin{array}{l}\text { Thermal sum } \\
\text { accumulated } \\
\text { oday }\end{array}$ & $\begin{array}{l}\text { Precipitation } \\
\text { accumulated } \\
\mathrm{mm}\end{array}$ \\
\hline 2013 & $25 / 05$ to $11 / 12$ & 14.45 & 24.01 & 182.08 & 5.25 & 1051.15 & 580.90 \\
2014 & $02 / 07$ to $30 / 10$ & 14.59 & 24.50 & 70.76 & 0 & 670.90 & 222.10 \\
\hline
\end{tabular}
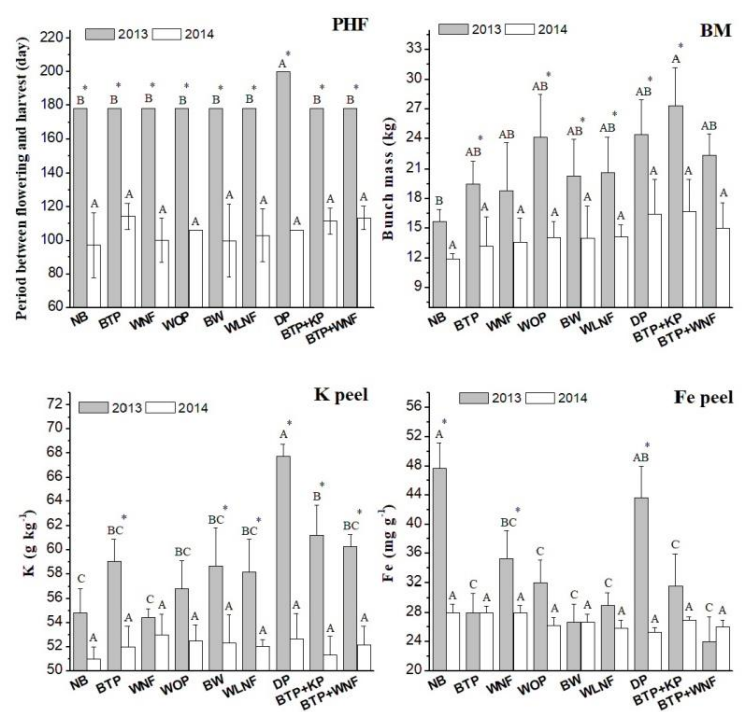

Fig 1. Period between flowering and harvest (PFH), bunch mass (BM), K (K peel) and Fe (Fe peel) content in the peel of the ripe fruits, depending on bagging material and year of formation of bunch banana cv. Prata. Vertical bars represent the standard deviation of the mean. Means on columns with the same color (year) and with the same letter are not significantly different by Tukey's test $(p<0.05)$. Asterisks indicate differences between the years of formation of bunch by $F$ test $(p<0.05)$.

Table 2. Bunch of characteristics and ripe fruits of banana cv. Prata depending on the year of formation.

\begin{tabular}{|c|c|c|c|c|c|c|c|c|c|}
\hline & $\begin{array}{c}\text { SM } \\
\text { kg }\end{array}$ & $\mathrm{HN}$ & $\mathrm{Cl}$ index & & $a^{*}$ & $b^{*}$ & $L^{*}$ & $C^{*}$ & $\begin{array}{c}\mathrm{SL} \\
\text { day }\end{array}$ \\
\hline 2013 & 2.11 & 8.82 & $1.38 \mathrm{a}$ & & $1.72 \mathrm{~b}$ & $53.50 \mathrm{~b}$ & 71.65 & $54.01 \mathrm{~b}$ & $12.47 b$ \\
\hline 2014 & 2.03 & 8.56 & $1.00 \mathrm{~b}$ & & $3.11 \mathrm{a}$ & $58.16 \mathrm{a}$ & 71.98 & $58.26 \mathrm{a}$ & $24.26 \mathrm{a}$ \\
\hline mean & 2.07 & 8.68 & 1.19 & & 2.45 & 55.95 & 71.83 & 56.25 & 18.21 \\
\hline vc (\%) & 20.45 & 14.14 & 4.32 & & 20.11 & 7.86 & 2.11 & 7.08 & 19.23 \\
\hline \multirow[t]{3}{*}{$\mathrm{F}$} & $0.53^{\mathrm{ns}}$ & $0.88^{\mathrm{ns}}$ & $49.32 * *$ & & 19.25 & $21.29 * *$ & $0.91^{\mathrm{ns}}$ & $21.60 * *$ & $73.15^{* *}$ \\
\hline & $\mathrm{ML}$ & $\mathrm{F}$ & $\mathrm{pH}$ & TSS & TA & SS & $\mathrm{S}$ & DMpeel & DMpulp \\
\hline & $\%$ & $\mathrm{~N}$ & & ${ }^{\circ}$ Brix & $\%$ & $\%$ & $\%$ & $\%$ & $\%$ \\
\hline 2013 & $5.25 \mathrm{~b}$ & 1.02 & 4.11 & 25.85 & 0.89 & $22.31 b$ & $2.99 a$ & 10.91 & $29.40 \mathrm{a}$ \\
\hline 2014 & $5.93 \mathrm{a}$ & 1.10 & 4.99 & 25.96 & 0.88 & $23.25 \mathrm{a}$ & $2.25 \mathrm{~b}$ & 10.90 & $27.07 \mathrm{~b}$ \\
\hline mean & 4.68 & 10.38 & 4.58 & 25.91 & 0.88 & 22.78 & 2.62 & 10.90 & 28.30 \\
\hline vc (\%) & 16.57 & 15.05 & 40.51 & 9.22 & 9.72 & 6.72 & 12.74 & 11.67 & 13.59 \\
\hline $\mathrm{F}$ & $14.07^{* *}$ & $0.27^{\mathrm{ns}}$ & $4.31^{*}$ & $0.32^{\mathrm{ns}}$ & $1.03^{\mathrm{ns}}$ & $7.20 * *$ & $79.45^{* *}$ & $0.01^{\mathrm{ns}}$ & $7.80 * *$ \\
\hline
\end{tabular}

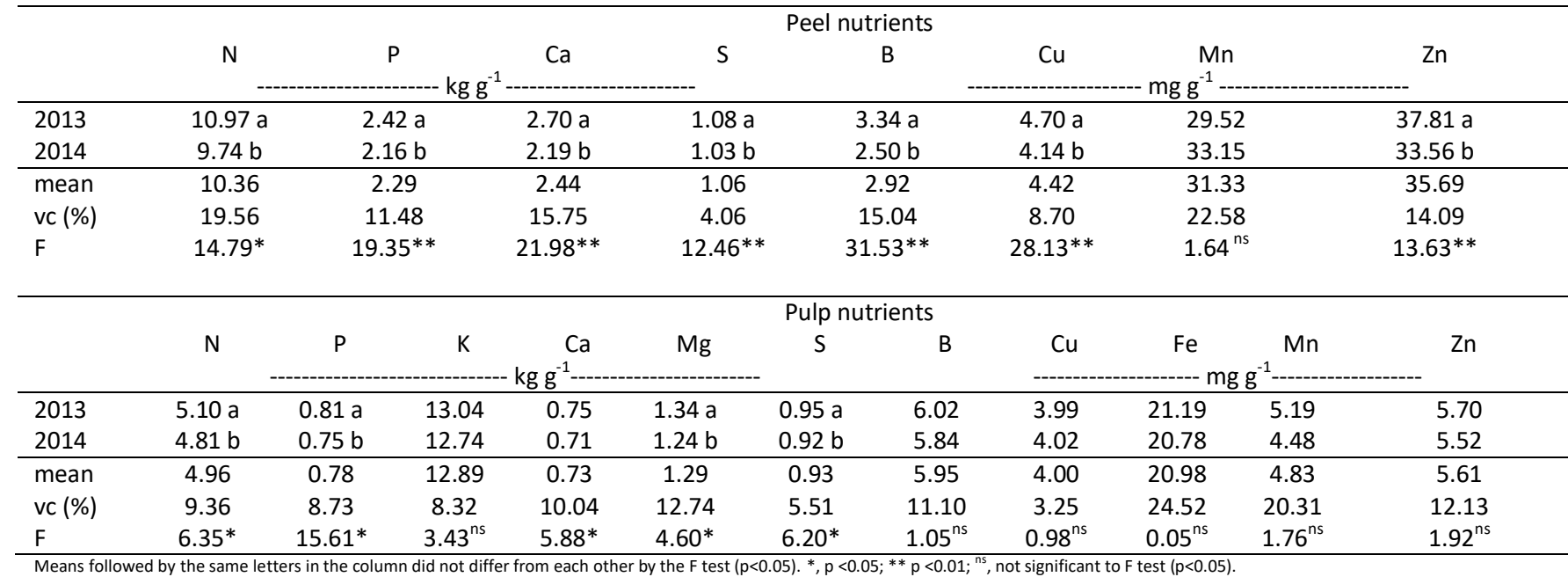




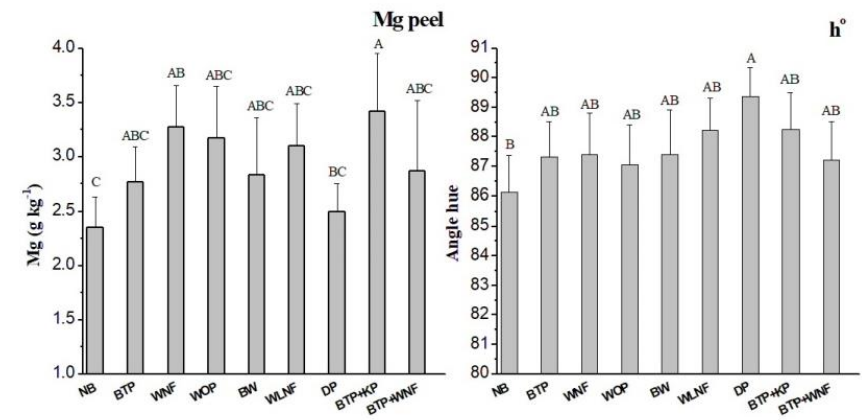

Fig 2. Mg content and angle hue in the peel of the ripe fruits, depending on bagging material of banana cv. Prata. Vertical bars represent the standard deviation of the mean. Means on columns with the same letter are not significantly different by Tukey's test ( $p<0.05)$

\begin{tabular}{|c|c|c|c|c|}
\hline \multirow[t]{2}{*}{ Material } & $* \Delta$ Mean & Standard deviation & Min & Max \\
\hline & \multicolumn{4}{|c|}{$16: 05 \mathrm{~h}$ of $22 / 07$ to $07: 05$ of $23 / 07 / 2013-\mathrm{Tmin}=6.29^{\circ} \mathrm{C}$. } \\
\hline BTP-NB & 1.31 & 0.60 & 0.26 & 2.47 \\
\hline WFN-NB & 0.77 & 0.40 & 0.04 & 1.58 \\
\hline WOP-NB & 1.91 & 0.85 & 0.28 & 3.43 \\
\hline BW-NB & 1.40 & 0.72 & 0.05 & 2.73 \\
\hline WLNF-NB & 1.45 & 0.87 & 0.18 & 2.95 \\
\hline DP-NB & 1.08 & 0.54 & 0.13 & 2.13 \\
\hline $\mathrm{BTP}+\mathrm{WFN}-\mathrm{NB}$ & 1.48 & 0.60 & 0.37 & 2.60 \\
\hline
\end{tabular}

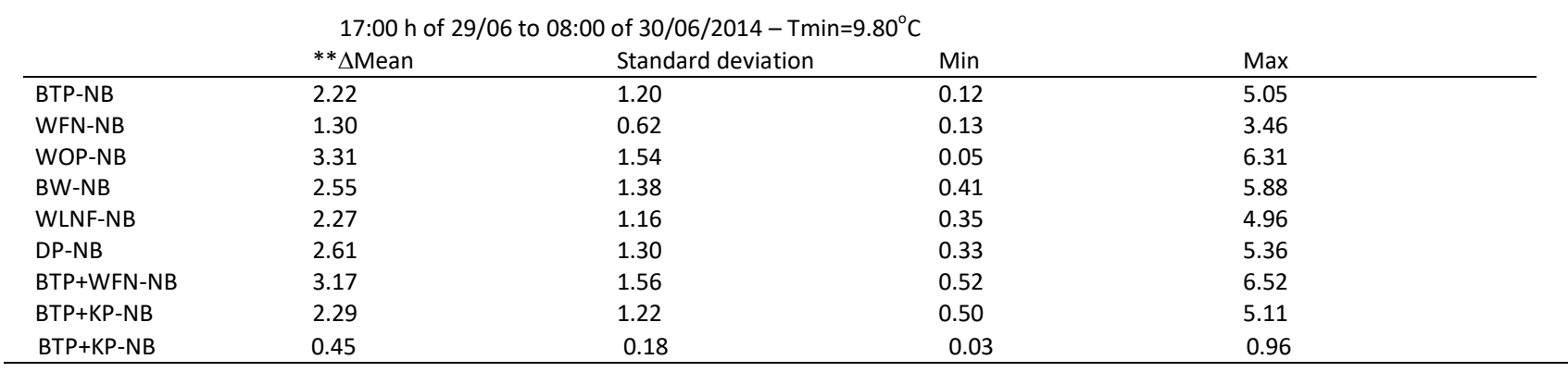

Table 4. Characteristics of bunch cover.

\begin{tabular}{|c|c|c|c|c|}
\hline Material & Thickness & $\begin{array}{l}\text { Dimension } \\
\text { length } \mathrm{x} \text { width }\end{array}$ & $\begin{array}{l}\text { Diameter } \\
\text { perforation } \\
\text { and spacing }\end{array}$ & $\begin{array}{c}\text { Radiation } \\
\text { transmissivity }\end{array}$ \\
\hline $\begin{array}{l}\text { Blue transparent polyethylene } \\
\text { (BTP) }\end{array}$ & $3 \mu$ & $1.50 \times 0.75 \mathrm{~m}$ & $\begin{array}{l}0.008 \mathrm{~m} \text { diameter } \\
\text { every } 0.18 \times 0.14 \mathrm{~m}\end{array}$ & $88.3 \%$ \\
\hline White non-woven fabric (WNF) & $\begin{array}{l}15 \mathrm{~g} \mathrm{~m}^{-2} \\
3 \mu\end{array}$ & $1.50 \times 0.80 \mathrm{~m}$ & absent & $90.5 \%$ \\
\hline $\begin{array}{l}\text { White opaque polyethylene } \\
\text { (WOP) }\end{array}$ & $60 \mu$ & $1.60 \times 0.77 \mathrm{~m}$ & $\begin{array}{l}0.008 \mathrm{~m} \text { diameter } \\
\text { every } 0.18 \times 0.14 \mathrm{~m}\end{array}$ & $76.2 \%$ \\
\hline Bubble wrap (BW) & $\begin{array}{l}25 \mathrm{~g} \mathrm{~m}^{-2} \\
3 \mu\end{array}$ & & absent & $88.1 \%$ \\
\hline $\begin{array}{l}\text { White laminated } \\
\text { non-woven (WLNF) }\end{array}$ & $\begin{array}{l}26 \mathrm{~g} \mathrm{~m}^{-2} \\
10 \mu\end{array}$ & $1.65 \times 0.80 \mathrm{~m}$ & absent & $45.2 \%$ \\
\hline Double paper (DP) & $\begin{array}{l}\text { Kraft paper: } \\
80 \mathrm{~g} \mathrm{~m}^{-2} \\
\text { blue paper } 17 \mathrm{~g} \mathrm{~m}^{-2}\end{array}$ & $1.70 \times 0.80 \mathrm{~m}$ & absent & $4.8 \%$ \\
\hline $\begin{array}{l}\text { Blue transparent polyethylene }+ \\
\text { Kraft paper }(B T P+K P)\end{array}$ & $\begin{array}{l}\text { blue polyethylene } \\
3 \mu \\
\text { Kraft paper: } \\
64 \mathrm{~g} \mathrm{~m}^{-2}\end{array}$ & $\begin{array}{l}1.50 \times 0.75 \mathrm{~m} \\
0.90 \times 0.80 \mathrm{~m}\end{array}$ & $\begin{array}{l}\text { polyethylene: } \\
0.008 \mathrm{~m} \text { diameter } \\
\text { every } \\
0.18 \times 0.14 \mathrm{~m} \\
\text { Kraft paper: absent }\end{array}$ & $7.3 \%$ \\
\hline $\begin{array}{l}\text { Blue transparent polyethylene }+ \\
\text { white non-woven fabric } \\
(\text { BTP+WNF) }\end{array}$ & $\begin{array}{l}\text { polyethylene } 3 \mu \\
\text { non-woven fabric } \\
15 \mathrm{~g} \mathrm{~m}^{-2} ; 3 \mu\end{array}$ & $\begin{array}{l}\text { polyethylene } 1.50 \mathrm{x} \\
0.75 \mathrm{~m} \\
\text { non-woven fabric } \\
1.50 \times 0.80 \mathrm{~m}\end{array}$ & $\begin{array}{l}\text { polyethylene: } \\
0.008 \mathrm{~m} \text { diameter } \\
\text { every } \\
0.18 \times 0.14 \mathrm{~m} \\
\text { non-woven fabric: } \\
\text { absent }\end{array}$ & $66.7 \%$ \\
\hline
\end{tabular}

\footnotetext{
* Transmissivity was measured using a portable light meter under illuminance light of $840 \mathrm{klx} . \mu=0,001 \mathrm{~mm}$
} 
the peel surface temperature compared to non-bagged fruits, up to 1.91 and $3.17^{\circ} \mathrm{C}$ (Table 3), respectively, agreeing with results of Harvey (2006); Chonhenchob et al. (2011); Kutinyu et al. (2014). In this condition, WOP, followed by BTP + WFN were the most efficient materials. However, considering $12^{\circ} \mathrm{C}$ as the threshold temperature for the occurrence of $\mathrm{Cl}$ (Nguyen et al., 2003), none of the materials was able to prevent stress. WOP stands out due to the greater thickness, high transmittance of radiation in the visible region, but a certain degree of opacity, which prevents the reflection of the radiation in the infrared region, concentrating heat on the inner surface of the film. BTP + WNF consists of high transmittance polyethylene, allowing the absorption of a large part of the incident radiation and its concentration on the outer surface of the WFN, because it is a very porous material, preventing heat loss. It is recommended for subtropical regions (Mustaffa and Kumar, 2012). Harvey (2006) proved that increasing layers reduces heat transfer and has detected lower infrared radiation transmission by BW in relation to BTP, which explains its higher temperature conservation capacity on colder days. Infrared radiation has less energy per photon than visible radiation, but causes warming of the object that irradiates. For the two years of bunch formation, BTP was the material that showed lower efficiency.

Bagging can keep high humidity (Chonhenchob et al., 2011; Sarkar et al., 2014), resulting in a reduction of water loss and increase in cell turgor pressure (Chonhenchob et al., 2011). In India, the bagging of bunches with transparent

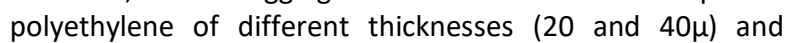
perforation percentage $(20,30$ and $30 \%)$ promoted a rise of up to $1.5^{\circ} \mathrm{C}$ in temperature and up to $9 \%$ in relative humidity (Sarkar et al., 2014). In Africa, bagging with polyethylene (non-perforated and perforated) and cheese cloth bags raised the temperature up to $3^{\circ} \mathrm{C}$ when the minimum surface temperature of unprotected fruit peel reached 12 $13^{\circ} \mathrm{C}$, sufficient to prevent $\mathrm{Cl}$ (Kutinyu et al., 2014).

In 2013, the PFH of PD-bagged bunches was the most extensive without any differences between the other materials (Fig 1), probably due to lower radiation transmissivity (Table 4) and its effect on the reduction of peel photosynthesis. In 2014; however, there were no differences among treatments.

Except for NB and WNF, in which there were no significant differences for BM between the two years of bunch formation, the difference in bunch mass between 2013 and 2014 was at least $3.7 \mathrm{~kg}$. In both years, although the difference was not significant, BM tended to be higher in the presence of the bagging due to alteration of temperature and better fruit filling (Pathak et al., 2017). In 2013, bunches bagged with BTP+KP showed higher BM when compared to $\mathrm{NB}$, not differing from other materials (Fig 1). According to Pathak et al. (2017), the increased layering has been used to raise the temperature of the growing environment of the fruit. In 2014, there were no significant differences among treatments.

The influence of the bagging material on the $\mathrm{K}$ and $\mathrm{Fe}$ content of peel was significant only in 2013 (Fig 1). For K, DPbagged bunches exhibited the highest contents, while WFN and NB showed the lowest contents. However, other treatments did not differ. The highest $K$ content in DP was due to the more intense radiation reduction (Table 4), which generated the need for greater translocation of photoassimilates from other parts associated with $\mathrm{K}$ (Silva et al., 2013), as well as to the higher PFH (Table 3). The $K$ content in fruit peel in 2013 was higher than 2014, except for NB, WFN and WOP, which may be related to higher water availability in 2013 (Fig 1). For both years, regardless of material, the $\mathrm{K}$ content in fruits was always higher than the average value (Aquino et al., 2014).

The Fe content in peel was higher in NB, followed by DP, WFN, and in the sequence of other materials that did not differ from each other (Fig 1). The possible reasons for the highest Fe content in NB are: (1) higher translocation due to higher transpiration rate; (2) contamination by Fe present in the dust, which agrees with the soil type be hyperferric (Embrapa, 2013); and (3) maintenance of the rate of absorption and translocation even when the growth rate of the bunch was low, agreeing with the fact that the NB exhibited the lowest BM (Fig 1). For PD, probably the highest Fe content in the peel should be related to higher PFH.

Regardless the year of bunch formation, the $\mathrm{Mg}$ content was higher in bunches bagged with BTP + KP and lower in NB, and the other materials showed intermediate levels (Fig 2). The lower Mg contents in the peel of NB fruits, followed by $D P$, may be due to the less photosynthesis (Marschner, 2012). The NB may have caused by the lower temperature on the peel surface and PD may be a consequence of the lower light availability (Table 4), which also resulted in higher PFH (Fig 1).

None of the color components of the green fruit peel and $\mathrm{Cl}$ index were influenced by the bagging material, as well as the content of phenols and total chlorophylls, which were also independent of the year of bunch formation. That is regardless of the climatic conditions in the PFH. According to Hashim et al. (2012), the $\mathrm{Cl}$ symptom is due to oxidative polymerization of phenols and chlorophyll deterioration. The mean chlorophyll content in the peel of green fruits was about $30.19 \mathrm{mg} \mathrm{g}^{-1} \mathrm{FW}$, which was reduced throughout the postharvest without apparent alteration. The content of phenols in the peel of green fruits $\left(2.43 \mathrm{mg} \mathrm{g}^{-1} \mathrm{FW}\right)$ was similar to that determined by Nguyen (2003) and Zapata et al. (2015) for cultivar from the AAA subgroup. Regarding the coloration of mature fruits, only $\mathrm{h}^{\circ}$ was influenced by the bagging material, but independently in the year of bunch formation (Fig 2). Fruits bagged with PD showed higher $h^{\circ}$ compared to NB, and there were no differences among the other treatments. The mean $h^{\circ}$ value exhibited by treatments was 87.60 , or near 90 , which is the yellow color desired for ripe fruit.

\section{Materials and Methods}

\section{Experimental area and plant material}

The experiment was conduct at Univale farm, located at Jacupiranga, state of São Paulo, Brazil and situated at an altitude of $80 \mathrm{~m}$ above sea level, $24^{\circ} 24^{\prime} 00^{\prime \prime} \mathrm{S}$ latitude and $48^{\circ} 0^{\prime} 00^{\prime \prime} \mathrm{W}$ longitude). The climate of the region according to the Köppen's classification is Af; tropical rainy without dry season (Alvares et al., 2013). Data from a series of last 15 years, recorded by CIAGRO, Instituto Agronômico de Campinas, indicates that the mean annual minimum and maximum temperatures were $17.2{ }^{\circ} \mathrm{C}$ and $27.4{ }^{\circ} \mathrm{C}$, respectively, and that the average annual rainfall was 1608.2 $\mathrm{mm}$ per year. 
The soil is classified in the Brazilian System of Classification of Soils as Haplic Cambisol (Embrapa, 2013), with 420, 110 and $470 \mathrm{~g} \mathrm{~kg}^{-1}$ of clay, silt and sand, respectively. The $0-20$ $\mathrm{cm}$ layer of the soil had the following characteristics in 2013: organic matter $(\mathrm{OM})=24 \mathrm{~g} \mathrm{dm}^{-3} ; \mathrm{pH}$ in water $=5.7 ; \mathrm{P}$ resin $=$ $11 \mathrm{mg} \mathrm{dm}^{-3} ; \mathrm{K}, \mathrm{Ca}, \mathrm{Mg}$, potential acidity $(\mathrm{H}+\mathrm{Al})$, exchangeable acidity (Al) and cation exchange capacity (CEC) (mmolc dm ${ }^{-3}$ ) $=1.3,24,11,26,0$ and 62.3 , respectively; and base saturation (V\%) $=58,27 \%$; S, B, Fe, Mn, $\mathrm{Cu}$ and $\mathrm{Zn}\left(\mathrm{mg} \mathrm{dm}^{-3}\right)$ $=8.2,0.3,500,18,1.8$ and 5.0. In 2014, the chemical characteristics exhibited were: organic matter $(\mathrm{OM})=26 \mathrm{~g}$ $\mathrm{dm}^{-3} ; \mathrm{pH}$ in water $=6.0 ; \mathrm{P}$ resin $=6 \mathrm{mg} \mathrm{dm}^{-3} ; \mathrm{K}, \mathrm{Ca}, \mathrm{Mg}$, potential acidity $(\mathrm{H}+\mathrm{Al})$, exchangeable acidity (Al) and cation exchange capacity (CEC) (mmolc $\left.\mathrm{dm}^{-3}\right)=1.3,38,20,21,0$ and 80.3 , respectively; and base saturation $(\mathrm{V} \%)=73.85 \% ; \mathrm{S}$, $\mathrm{B}, \mathrm{Fe}, \mathrm{Mn}, \mathrm{Cu}$ and $\mathrm{Zn}\left(\mathrm{mg} \mathrm{dm}^{-3}\right)=3.2,0.2,440,14,2.0$ and 13.5.

Planting was performed in 2011 in a density of 1330 plants ha $^{-1}$ using contamination-free banana tissue-cultured plants (Musa spp. AAB group, Prata subgroup, cv. Prata). In this research inflorescences from $3^{\text {rd }}$ and $4^{\text {th }}$ cycle of fruit production were used. All the cultural treatments necessary for good production were carried out.

\section{Experimental design and treatments}

A completely randomized design in a $2 \times 9$ factorial was adopted for two years of bunch formation (2013 and 2014) and nine covers, with eight replicates. The materials consisted of BTP, WNF, WOP, BW, WLNF, DP, BTP+KP, $B T P+W N F$ and NB (control) (Table 4). Bagging was carried out in autumn (2013) and winter (2014) to ensure the occurrence of stress temperature $\left(<12^{\circ} \mathrm{C}\right)$ in the field, after the complete opening of bracts of the inflorescences. The climatic conditions during the experimental period were presented in Table 1.

\section{Variables assessed}

A temperature reading system was installed to collect data on the surface of fruits and the environment. For this, Datalloger Campbell Scientific, Logan, Utah, USA, Model CR 1000 was used, with data collection interval of five minutes. Mean daily temperatures and cumulative rainfall were recorded at a meteorological station (Campbell Scientific, Logan, Utah, USA) located $10 \mathrm{~km}$ from the experimental site. The thermal sum in degree-days was calculated using $14^{\circ} \mathrm{C}$ as baseline temperature (Ganry and Meyer, 1975).

Bunches were harvested when fruits from the last hand reached $3 \mathrm{~cm}$ in diameter and the number of hands, bunch mass and stalk mass were recorded.

The $\mathrm{Cl}$ index was scored visually based on the intensity of surface browning of banana, according to methodology established by Nguyen et al. (2003), as follows: $1=$ no $\mathrm{Cl} ; 2=$ mild injury; $3=$ moderate injury; $4=$ severe injury; $5=$ very severe injury. At score 2 , there is no visible browning on the skin surface but if the epidermal tissues are peeled, grayish areas are found close to the surface. At score 3 there are more areas like that, which are larger and darker with several forms of continuous lines. At score 4, grayish brown patches are visible on the skin. Cross section of the peel shows larger and darker areas at score 3. At score 5, there are relatively large dark patches on the skin surface.
Three peel discs (9 $\mathrm{mm}$ diameter) were removed from one side of fruit banana and incubated with dimethyl sulfoxide for $24 \mathrm{~h}$ in the dark (Hiscox and Israelstam, 1979). The supernatant was used to determine the chlorophyll content according to the method of Wellburn (1994) in a spectrophotometer Shimadzu UV-1601 (Japan).

Total phenolics in peel tissues were determined according to the Folin-Ciocalteu procedure, using the method described by Singleton et al. (1999). The extraction was carried out with ethanol by $24 \mathrm{~h}$ in the dark. Peel tissues were homogenized with methanol and extracted for $18 \mathrm{~h}$ in the dark. Then the homogenate was filtered and centrifuged. The compounds reacted with Folin-Ciocalteu reagent and $\mathrm{Na}_{2} \mathrm{CO}_{3}$ and the quantification was conducted in a spectrophotometer Shimadzu UV-1601.

The color of the peel of the green and ripe fruit was measured at four locations around equatorial region on each fruit using a colorimeter (CR-400, Minolta, Tokyo, Japan) calibrated using a standard white plate. The illuminant was D65 and color was measured using the CIE $L^{*} a^{*} b *$ system. L* denotes brightness $(0=$ black and $100=$ white $)$ and chromatic co-ordinates $a^{*}\left(+a^{*}=\right.$ green and $-a^{*}=$ red), $b^{*}$ $\left(+b^{*}=\right.$ yellow and $-b^{*}=$ blue $)$. The hue angle $\left(\mathrm{h}^{\circ}\right)$ and chromaticity $\left(C^{*}\right)$ were calculated by the equations $h^{\circ}=\tan ^{-1}$

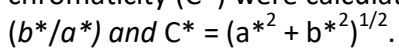

Hand 4 was stored at $25^{\circ} \mathrm{C}$ and $85-95 \%$ relative humidity up to stage 6 of the Von Loeseck scale (1950) was reached for shelf life determination and analyses in maturity.

Shelf life was then determined as the number of days taken by the fruit to progress from ripeness stage 6 of the Von Loeseck (1950)

Physiological losses in mass of the fruit was determined with equation on the basis of initial mass of the green fruit and loss at maturity and expressed in percent: $\mathrm{ML}=[(\mathrm{Mf}-$ $\mathrm{Mi}) / \mathrm{Mi}] \times 100$. Where; $\mathrm{ML}$ is mass loss, $\mathrm{Mi}$ is the initial fruit mass and $M f$ is fruit mass at maturity.

Fruit firmness was measured with the help of 'Penetrometer' (Model FT-327, QA Supplies, Norfolk, VA, USA) after removing a portion of the peel. The pressure required to force a stainless steel probe of $8 \mathrm{~mm}$ (in diameter) into banana was recorded and the results were given in Newtons (N).

Titratable acidity (TA) soluble solids (SS) content and $\mathrm{pH}$ were determined after homogenizing a portion of the pulp with distilled water. Titratable acidity was measured using titration method with $0.1 \mathrm{~N} \mathrm{NaOH}$ up to $\mathrm{pH} 8.0$ in the presence of phenolphthalein (AOAC, 2005) and expressed as percentage of malic acid. The $\mathrm{pH}$ was measured using a Tecnal (Piracicaba, Brazil) pH meter calibrated by $\mathrm{pH} 4$ and 6.4 buffer solutions (AOAC, 2005). Total soluble solids content was determined with the help of an Atago (Japan) hand refractometer and results expressed as ${ }^{\circ}$ Brix (Tressler and Joslyn, 1961).

Soluble sugars were determined after extracting with hot ethanol and reaction with anthrone (Hodge and Hodfreiter, 1962), and starch quantified in residue from ethanol extraction of soluble sugars (McCready et al., 1950; Patel, 1970). Dry matter was determined by loss mass of samples pulp and peel of $10 \mathrm{~g}$ fresh mass following $48 \mathrm{~h}$ drying in a forced air oven $\left(65 \pm 2^{\circ} \mathrm{C}\right)$. The contents of nutrients were determined in the dry matter of peel and pulp according to Souza et al. (2016). 


\section{Statistical analysis}

Data of analyses were expressed as means of three replicate determinations. Statistical analysis was conducted with the SISVAR software (Ferreira, 2011). Mean comparisons were performed using the Tukey's test $(p \leq 0.05)$. To determine the behavior of variables during shelf life of fruits, the study conducted regression analyses and adopted linear, quadratic or cubic models. Plots in this paper were made by Origin 8.5.

\section{Conclusion}

The bagging materials used were not able to significantly raise the temperature on colder days. However, fruit exposure for 5.25 hours at temperature below $5^{\circ} \mathrm{C}$ during bunch formation caused mild symptoms of $\mathrm{Cl}$ on banana 'Prata', confirming its tolerance. The bagging material influenced yield (BM and PHF), the accumulation of nutrients in fruits and the peel color $\left(h^{\circ}\right)$. Double paper promoted fruits with more yellow peel $\left(\mathrm{h}^{\circ}\right)$.

\section{Acknowledgements}

The authors are grateful to FAPESP for the financial support (2012/01167-3), to Silvio Guatura Romão (UNIVALE), José Carlos de Mendonça (COMTÉCNICA) and José Alberto dos Santos (APTA) for the technical support.

\section{References}

Al-Mahdouri A, Baneshi M, Gonome H, Okajima J, Maruyama S (2013) Evaluation of optical properties and thermal performances of different greenhouse covering materials. Sol Energy. 96:21-32.

Alvares CA, Stape JL, Sentelhas PC, Gonçalves JLM, Sparovek G (2013) Köppen's climate classification map for Brazil. Meteorol Z. 22:711-728.

Aquino CF, Salomão LCC, Siqueira DL, Cecon PR, Ribeiro SMR (2014) Teores de minerais em polpas e cascas de frutos de cultivares de bananeira. Pesq Agropec Bras. 49:546-553.

Association of Oficial Analytical Chemists (AOAC) (2005) Official Methods of Analysis, 16th edn. AOAC International, Washington, DC

Bidabadi SS, Mahmood M, Meon S, Wahab Z, Ghobadi C (2011) Evaluation of in vitro water stress tolerance among EMS-induced variants of banana (Musa spp., AAA), using morphological, physiological and molecular traits. J Crop Sci Biotechnol. 14:255-263.

Cho JS, Lee HJ, Park JH, Sung JH, Choi JY, Moon KD (2016) Image analysis to evaluate the browning degree of banana (Musa spp.) peel. Food Chem. 94:1028-1033.

Chonhenchob V., Kamhangwong, D, Kruenate J, Khongrat K, Tangchantra N, Wichaid U, Singh SP (2011) Preharvest bagging with wavelength-selective materials enhances development and quality of mango (Mangifera indica L.) cv. Nam Dok Mai. \#4. J Sci Food Agric. 91:664-671.

Der Agopian RG, Peroni-Okita FHG, Soares CA, Mainardi JA, Nascimento JRO, Cordenunsi BR, Lajolo FM, Purgatto E (2011) Low temperature induced changes in activity and protein levels of the enzymes associated to conversion of starch to sucrose in banana fruit. Posth Bio \& Tech. 62:133-140.
Embrapa (2013) Sistema brasileiro de classificação de solos, 3rd edn. Embrapa Solos, Rio de Janeiro.

Ferreira DF (2011) Sisvar: a computer statistical analysis system. Ciênc Agrotec. 35:1039-1042.

Ganry J, Meyer JP (1975) Recherche d'une loi d'action de la température sur la croissance des fruits du bananier. Fruit. 30:375-392.

Hashim N, Janius RB, Baranyai L, Rahman RA, Osman A, Zude $M$ (2012) Kinetic model for colour changes in bananas during the appearance of chilling injury symptoms. Food Bioprocess Tech. 5:2952-2963.

Harvey BV (2006) Mild chilling injury of banana (Cavendish cv. Williams) and its control in the field. PhD Thesis, University of Adelaide, Australia, September 2005.

Hiscox JD, Israelstam GF (1979) A method for the extraction of chlorophyll from leaf tissue without maceration. Can J Bot. 57:1332-1334.

Hodge JE, Hodfreiter BR (1962) Determination of reducing sugars and carbohydrate. In: Wilster RC, Wolfron MI (eds) Methods in carbohydrates chemistry. Academic Press, New York. 1.

Kutinyu R, Fraiser C, Ngezimana W, Mudau FN (2014) Evaluation of banana bunch protection materials for optimum fruit production on cultivars grown in Mozambique. Trop Agr. 91:109-115.

Marschner H (2012) Mineral nutrition of higher plants, 3rd edn. Academic Press, New York.

Muchui MN (2012) Influence of fertilizers, harvest maturity, polyethylene bunch covers and postharvest treatment with 1-Methylcyclopropene on physical, physiological and biochemical quality of tissue-cultured bananas (Musa spp.). PhD Thesis, University of Jomo Kenyatta, Kenya, November 2012.

Mustaffa MM, Kumar V (2012) Banana production and productivity enhancement through spatial, water and nutrient management. J Hortic Sci. 7:1-28.

Nguyen TBT, Ketsa S, Van Doorn WG (2003) Relationship between browning and the activities of polyphenol oxidase and phenylalanine ammonia lyase in banana peel during low temperature storage. Posth Bio \& Tech. 30:187-193.

Oliveira JAA, Salomao LCC, Siqueira DL, Cecon PR (2016) Cold tolerance of banana fruits of different cultivars. Rev Caatinga. 29:629-641.

Patel RZ (1970) A note on the seasonal variations in starch content of different parts of Arabica coffee trees. E Afr Agri Forestry J. 36:1-4.

Pathak P, Bhattacharyya RK, Baishya BK, Das U, Das J (2017) A review of works done regarding the impact of bunch cover application in banana. Int J Curr Microbiol App Sci. 6:2181-2194

Robinson JC, Saúco VG (2012). Plátanos y bananas, 3rd edn. Eujoa Artes Gráficas, Madrid.

Zapata LCR, Gil FLE, Martínez SC, May CRT, Marin FC, Fuentes G, Duch ES, Santamaría, JM (2015) Preharvest foliar applications of glycine-betaine protects banana fruits from chilling injury during the postharvest stage. Chem Biol Technol Agric. 2:4-10.

Sarkar S (2014) Shooting-harvest interval and physicochemical properties of banana (Musa AAA cv. Grand Naine) in relation to micro climate inside the bunch cover. Asian J Horti. 9:40-42. 
Santosh DT, Tiwari KN, Reddy RG (2017) Banana bunch covers for quality banana production - a review. Int J Curr Microbiol Appl Sci. 6:1275-1291.

Silva JTA, Rodrigues MGV (2013) Avaliação nutricional, produção e incidência do Mal-do-Panamá em bananeira 'Prata-Anã' (AAB) adubada com K, no quarto ciclo. Rev Bras Frutic. 35:1170-1177.

Singleton VL, Orthofer R, Lamuela-Raventos RM (1999) Analysis of total phenols and other oxidation substrates and antioxidants by means of Folin-Ciocalteu reagent. Methods Enzymol. 299:152-178.

Souza HA, Parent SÉ, Rozane DE, Amorim DA, Modesto VC, Natale W, Parent LE (2016) Guava waste to sustain guava (Psidium guajava) agroecosystem: nutrient-balanceconcepts. Front Plant Sci. 29:1252.
Tressler DL, Joslyn MA (1961) Fruits and vegetables juiceprocessing technology. AVI Publishing, Wetsport.

Von Loesecke HW (1950) Bananas. 2nd edn. Interscience Publish Inc, New York.

Wellburn AR (1994) The spectral determination of chlorophyll $a$ and $b$, as well as total carotenoids, using various solvents with spectrophotometers of different resolution. J Plant Physiol. 144:307-313.

Zhang JZ, Zhang Q, Chen YJ, Sun LL, Song LY, Peng CL (2012) Improved tolerance toward low temperature in banana (Musa AAA Group Cavendish Williams). S Afr J Bot. 78:290294. 